\title{
High temperature suppressed SSC self- renewal through $S$ phase cell cycle arrest but not apoptosis
}

\author{
Jia Wang ${ }^{1 \dagger}$, Wei-Jun Gao ${ }^{1 \dagger}$, Shou-Long Deng ${ }^{2}$, Xiang Liu' ${ }^{1}$, Hua Jia ${ }^{1,3^{*}}$ and Wen-Zhi Ma ${ }^{1,3^{*}}$
}

\begin{abstract}
Background: High temperature has a very adverse effect on mammalian spermatogenesis and eventually leads to sub- or infertility through either apoptosis or DNA damage. However, the direct effects of heat stress on the development of spermatogonial stem cells (SSCs) are still unknown because SSCs are rare in the testes.

Methods: In the present study, we first used in vitro-cultured SSCs to study the effect of heat shock treatment on SSC development. Then, we used RNA-Seq analysis to identify new genes or signalling pathways implicated in the heat stress response.

Results: We found that $45 \mathrm{~min}$ of $43^{\circ} \mathrm{C}$ heat shock treatment significantly inhibited the proliferation of SSCs $2 \mathrm{~h}$ after treatment but did not lead to apoptosis. In total, 17,822 genes were identified by RNA-Seq after SSC heat shock treatment. Among these genes, we found that 200 of them had significantly changed expression, with 173 upregulated and 27 downregulated genes. The number of differentially expressed genes in environmental information processing pathways was 37, which was the largest number. We screened the candidate JAK-STAT signalling pathway on the basis of inhibition of cell cycle progression and found that the JAK-STAT pathway was inhibited after heat shock treatment. The flow cytometry results further confirmed that heat stress caused S phase cycle arrest of SSCS.
\end{abstract}

Conclusion: Our results showed that heat shock treatment at $43^{\circ} \mathrm{C}$ for 45 min significantly inhibited SSC selfrenewal through $\mathrm{S}$ phase cell cycle arrest but not apoptosis.

Keywords: High temperature, SSCS, Self-renewal, Cell cycle arrest, Apoptosis

\section{Background}

Spermatogenesis is a process by which spermatogonial stem cells (SSCs) self-renew and differentiate into sperm. Any error during spermatogenesis results in male infertility. Infertility occurs in $10-15 \%$ of all couples, and male factors account for $50 \%$ of cases. High temperature is one of the causes of male infertility [1]. Cryptorchidism or increased scrotal temperature leads to nonobstructive azoospermia or asthenozoospermia.

\footnotetext{
*Correspondence: Huajia1981@yahoo.com; ma.wenzhi@gmail.com

${ }^{\dagger}$ Jia Wang and Wei-Jun Gao contributed equally to this work.

${ }^{1}$ Key Laboratory of Fertility Preservation and Maintenance of Ministry of Education, and Key Laboratory of Reproduction and Genetics of Ningxia Hui Autonomous Region, Department of Anatomy, Histology and Embryology, School of Basic Medical Science, Ningxia Medical University, Yinchuan 750004, China

Full list of author information is available at the end of the article
}

The scrotum is generally $2-7^{\circ} \mathrm{C}$ cooler than the core body temperature in most male mammals, and the temperature of the testes is tightly regulated by a heat exchange system [2]. If the testes fail to descend into the scrotum during postnatal development, they are exposed to elevated temperature (the core body temperature) and lose germ cells [3]. Male germ cells (especially haploid spermatids) are significantly reduced or completely lost in the cryptorchid testes [4]. The transition of gonocytes into type A dark spermatogonia (SSCs) in cryptorchid testes is impaired [5]. Thus, the thermoregulation of the testes is essential for spermatogenesis. The reason why most mammals have evolved to maintain their testes at low temperatures remains unclear [6].

Scrotal high temperatures led to the interruption of spermatogenesis and reductions in sperm quality and 
quantity $[7,8]$. Many experiments have shown that a single heat stress treatment of the testicles can induce apoptosis of heat-susceptible germ cells (late pachytene and diplotene spermatocytes and early round spermatids), resulting in the interruption of spermatogenesis and reversible transient sterility or DNA damage even if the germ cells escaped apoptosis. p53-dependent or p53independent pathways and p38 mitogen-activated protein kinase (MAPK) upstream signal activation are involved in mitochondria-mediated apoptosis of spermatogenic cells $[9,10]$. The apoptosis of spermatogenic cells causes depletion of spermatogenic cells in the seminiferous tubules, resulting in hollow tubules, spermatogenesis interruption and infertility. In addition, high temperatures can also cause sperm DNA breakage, oxidative damage and downregulation of protamine expression, which result in the destruction of sperm DNA integrity [11]. High temperature stress or varicocele increases the production of reactive oxygen species (ROS) in the testicles, and the excessive ROS attack lipoproteins and unsaturated fatty acids and damage proteins and DNA $[12,13]$. In general, the lack of superoxide dismutase (SOD) in the testicles makes spermatogenic cells more sensitive than other cells to heat stress [12, 1416]. The sperm in the epididymis is also affected by heat, which leads to sperm DNA damage that might result in subfertility of affected males or offspring deformity [17]. Spermatogonia are heat-tolerant germ cells. A study showed that stress granules are formed in spermatogonia after heat stress and confer resistance to apoptosis by suppressing the p38 MAPK pathway [18]. However, the direct effects of increased scrotal temperature on SSCs are still unknown because the number of SSCs accounts for as few as $0.03 \%$ of total adult testis cells [19].

In the present study, to provide insight into how heat shock treatment regulates the behaviour of SSCs, we first used in vitro-cultured SSCs to study the effects of heat shock treatment on SSC proliferation and apoptosis. Then, we used RNA-Seq analysis to identify new genes or signalling pathways implicated in the heat stress response.

\section{Materials and methods}

\section{SSC culture}

The CD1 SSC cell line from mice was donated by professor Wu Ji's laboratory from Shanghai Jiao Tong University. The culture medium was based on Minimum Essential Medium $\alpha$ (MEM- $\alpha$ ) (12571-063, Gibco, Grand Island, NY, USA) containing $2 \mathrm{mM}$ glutamine (G7012, Sigma, MO, USA), $10 \%$ foetal bovine serum (FBS) (16000-36, Gibco), 0.5× pen/strep (15240-062, Invitrogen, Grand Island, NY, USA), $1 \times$ nonessential amino acid (NEAA) (11140-050, Gibco) solution, $1 \times \beta$-mercaptoethanol ( $\beta$-ME) (M3148, Sigma), $25 \mu \mathrm{g} / \mathrm{ml}$ insulin
(I1882, Sigma), $100 \mu \mathrm{g} / \mathrm{ml}$ transferrin (T1428, Sigma), $60 \mu \mathrm{M}$ putrescine (P5780, Sigma), $60 \mathrm{ng} / \mathrm{ml}$ progesterone (P8783, Sigma), $40 \mathrm{ng} / \mathrm{ml}$ glial cell line-derived neurotrophic factor (GDNF) (512-GF-050, R\&D Systems, Minneapolis, MN, USA) and 3-5 ng/ml basic fibroblast growth factor (bFGF) (F0291, Sigma). The feeder layer cells were STO cells treated with mitomycin (M0503, Sigma). The SSCs were incubated at $37^{\circ} \mathrm{C}$ in the presence of $5 \% \mathrm{CO}_{2}$.

\section{Heat shock treatment}

The SSCs were divided into a control group and a heat shock-treated group. We seeded $1.6 \times 10^{4}$ cells per well into 6-cell plates or $2 \times 10^{3}$ cells per well into 96-cell plates, with six parallel wells for each group. The cells in the heat shock-treated group were cultured in a $5 \% \mathrm{CO}_{2}$ incubator at a constant temperature of $43^{\circ} \mathrm{C}$ for $10 \mathrm{~min}$, $15 \mathrm{~min}, 30 \mathrm{~min}, 45 \mathrm{~min}$ or $60 \mathrm{~min}$ and then transferred to another $5 \% \mathrm{CO}_{2}$ incubator at $37^{\circ} \mathrm{C}$. The cells in the control group were cultured in a $5 \% \mathrm{CO}_{2}$ incubator at $37^{\circ} \mathrm{C}$.

\section{Proliferation assay}

A CCK-8 kit (MAC218, Meilunbio, Dalian, China) was used to detect SSC proliferation in the control and heat shock-treated groups. CCK- 8 reagent $(10 \mu \mathrm{l})$ was added to the medium $(100 \mu \mathrm{l})$ in each well $2 \mathrm{~h}$ and $18 \mathrm{~h}$ after the heat shock treatment. After incubation for $2 \mathrm{~h}$, the optical density value (OD value) was measured at 450 $\mathrm{nm}$ using a microplate reader (Multiskan GO, Thermo Fisher Scientific, Rockford, IL, USA). A growth curve was drawn based on the mean value of the eight counts in each group.

\section{Immunofluorescence staining}

SSCs from the control and heat shock-treated groups were cultured in 24 -well plates $\left(0.8 \times 10^{3}\right.$ cells per well) and fixed with $4 \%$ paraformaldehyde at room temperature for $30 \mathrm{~min}$. The cells were treated with $0.5 \%$ Triton X-100 at room temperature for $15 \mathrm{~min}$ and washed three times with PBS at room temperature for 5 min each time. Then, the cells were incubated with $10 \%$ goat serum at room temperature for $40 \mathrm{~min}$. Then, the cells were incubated with polyclonal rabbit anti-GDNF receptor $\alpha-1$ (GFR $\alpha 1)$ (1:100; sc-10716, Santa Cruz Biotechnology, Santa Cruz, CA, USA) or polyclonal mouse anti-Promyelocytic Leukaemia Zinc Finger (PLZF) (1: 150, sc-22839, Santa Cruz Biotechnology) primary antibodies at $4{ }^{\circ} \mathrm{C}$ overnight. Finally, the cells were incubated with FITC- or TRITC-conjugated secondary antibodies (1:200, A22120-1, Abbkine, Wuhan, Chian) at $37^{\circ} \mathrm{C}$ for $30 \mathrm{~min}$ and stained with DAPI for $5 \mathrm{~min}$. We stained at least three sections for each group, and images were evaluated in at least three randomly selected fields per 
section under a magnification of $\times 400$ with an inverted fluorescence microscope (IX53, Olympus, Tokyo, Japan).

\section{Apoptosis detection}

SSCs from the control group and the heat shock-treated groups $\left(43^{\circ} \mathrm{C}, 45 \mathrm{~min}\right.$ or $60 \mathrm{~min}$ ) were cultured in 6-well plates at a density of $5 \times 10^{5}$ cells/well. Two and $18 \mathrm{~h}$ after the heat shock treatment, the cells were processed using an Annexin V-FITC Apoptosis Assay Kit (BB4101-2, Bestbio, China) according to the manufacturer's instructions. Briefly, cells were harvested, washed with 1 $\mathrm{ml}$ PBS and resuspended in $100 \mu \mathrm{l}$ staining buffer for 15 min at room temperature. After centrifugation, the staining buffer was aspirated, and cells were resuspended in $100 \mu \mathrm{l} \mathrm{PBS}$ for analysis. Samples were analyzed with the flow cytometer (BD Accuri ${ }^{\text {Tx }}$ C6, BD Biosciences). The 488-nm laser was used for excitation. Debris and doublets were gated out. At least 10,000 events of single cells per sample were collected. Additional single-labelled samples were prepared, which contain dead cells and serve as a positive control for single staining of Annexin V or PI, respectively. BD Accuri ${ }^{\text {Ti }}$ C6 Software was used to analyse the data. We also used ATUNEL BrightGreen Apoptosis Detection Kit (A211-01, Vazyme, Nanjing, China) to stain the apoptotic SSCs according to the manufacturer's protocol. Images were obtained with an inverted fluorescence microscope (IX53, Olympus).

\section{RNA-Seq and data analysis}

Total RNA was extracted from SSCs $2 \mathrm{~h}$ after the heat shock treatment using TRIzol Reagent (15596-018, Life Technologies, Carlsbad, CA, USA) following the manufacturer's instructions, and the RIN numbers were assessed to inspect RNA integrity with an Agilent Bioanalyzer 2100 (Agilent Technologies, Santa Clara, CA, USA). Qualified total RNA was further purified with an RNAClean XP Kit (A63987, Beckman Coulter, Inc., Kraemer Boulevard Brea, CA, USA) and an RNase-Free DNase Set (79254, Qiagen, GmBH, Germany). Total RNA $(1 \mu \mathrm{g})$ was also extracted from SSCs $2 \mathrm{~h}$ after the heat shock treatment and used for library preparation according to Illumina standard instructions (TruSeq Stranded RNA LT Guide). An Agilent 2100 Bioanalyzer was employed to evaluate the concentration and size distribution of the cDNA library before sequencing with an Illumina HiSeq. The protocol for high-throughput sequencing was fully performed in strict accordance with the manufacturer's instructions (Illumina). The raw reads were filtered with Seqtk before being mapped to the genome using TopHat (version: 2.0.9) [20]. The fragments of genes were counted using HTSeq followed by trimmed mean of $\mathrm{M}$ value (TMM) normalization [21, 22]. Significant differentially expressed genes (DEGs) were identified as those determined to have a false discovery rate $(\mathrm{FDR})$ passing the threshold $(Q<0.05)$ and a fold change $>2$ using edgeR software [23].

\section{Quantitative real-time PCR}

Some differentially expressed genes were validated by quantitative real-time (qRT) PCR. The primers were synthesized as shown in Table 1. We used the Tip Green qPCR SuperMix (AQ141, TransGen Biotech, Beijing, China) in a 20- $\mu$ l reaction volume on a 7500 Fast RealTime PCR System, and the reaction conditions were set at $94{ }^{\circ} \mathrm{C}$ for $30 \mathrm{~s}$ followed by $43 \mathrm{cycles}$ of $94{ }^{\circ} \mathrm{C}$ for $5 \mathrm{~s}$ and $60^{\circ} \mathrm{C}$ for $34 \mathrm{~s}$. The qRT-PCR primers were synthesized by Sangon Biotech (Shanghai) Co, Ltd. The data analysis was performed using the $2^{-\triangle \Delta \mathrm{CT}}$ method.

\section{Western blot}

The in vitro-cultured SSCs were collected, and protein lysates (keygentec, Nangjing, China) were extracted at $4{ }^{\circ} \mathrm{C}$ for $30 \mathrm{~min}$. The proteins were denatured in $5 \times$ SDS loading buffer at $100{ }^{\circ} \mathrm{C}$ for $5 \mathrm{~min}$. The total cell proteins were resolved by $12 \%$ SDS-PAGE and transferred onto PVDF membranes. After blocking with 5\% nonfat milk powder in TBST for $1 \mathrm{~h}$, the PVDF membranes were incubated with polyclonal rabbit anti-Osm (1:1000, A6163, ABclonal, Woburn, MA, USA), monoclonal mouse anti$\beta$ actin (1:1000, sc-58673, Santa Cruz Biotechnology), polyclonal rabbit anti-Socs3 (1:1000, 14025-1-AP, Proteintech, Wuhan, China), monoclonal rabbit anti-p-Stat3 (1:1000, ab76315, Abcam), polyclonal rabbit anti-p-Akt (1:1000, AF0016, AFFinify) and polyclonal rabbit antiGAPDH (1:1000, bs2188R, Bioss, Beijing, China) primary antibodies at $4{ }^{\circ} \mathrm{C}$ overnight. Then, horseradish peroxidase-conjugated goat anti-mouse or anti-rabbit(1:20000, A21020-1, Abbkine) secondary antibodies were used at room temperature for $1 \mathrm{~h}$, and the protein expression was detected by enhanced chemiluminescence (RM00021, ABclonal); gel imaging was performed with a ChemiDoc $^{\text {Tx }}$ XRS+ (Bio-Rad, USA) with Image Lab ${ }^{\text {tw }}$ software, and gray value analysis was performed with ImageJ.

\section{Cell cycle analysis}

SSCs from the control group and the heat shock-treated group $\left(43^{\circ} \mathrm{C}, 45 \mathrm{~min}\right)$ were seeded in 6 -well plates at the density of $2 \times 10^{5}$ cells/well. Two hours and $18 \mathrm{~h}$ after the heat shock treatment, the cells were trypsinized, collected and washed with PBS before $70 \%$ freezer-chilled ethanol was use to fix the cells for $2 \mathrm{~h}$ at $4{ }^{\circ} \mathrm{C}$. A cell cycle kit (KGA512, KeyGEN) was used to detect the SSC cycle according to the manufacturer's instructions. Briefly, cells resuspended in $500 \mu \mathrm{l}$ of propidium iodide buffer containing propidium iodide and ribonuclease $\mathrm{A}$ (9:1) were incubated in the dark for $40 \mathrm{~min}$. The intensity of fluorescence staining in the cells was measured 
Table 1 Primers used for qRT-PCR

\begin{tabular}{llll}
\hline Gene & Forward primer sequence $\left(5^{\prime}\right.$-3') $^{\prime}$ & Reverse primer sequence(5'-3') & Product length (bp) \\
\hline Oncostatin M (Osm) & ACTTCCTCCTTCCCTGTGG & CACCCAGAGGTCCAGGTATC & 101 \\
Socs3 & GTACTGAGCCGACCTCTCTC & ATCCAGGAACTCCCGAATGG & 129 \\
$\| 6$ ra & TGCTCTGCTTCAGGGAATGA & AGGCCACTCAGTCAAACGTA & 121 \\
\hline
\end{tabular}

using a flow cytometer (BD Accuri ${ }^{\text {Ti }}$ C6, BD Biosciences, USA). Debris and doublets were gated out. The particular phase of the cell cycle with DNA content in G0/G1, $\mathrm{S}$ and G2/M was estimated using BD Accuri $^{\mathrm{Tu}} \mathrm{C} 6$ software.

\section{JAK-STAT signalling pathway inhibition}

SSCs were plated at a density of $2 \times 10^{3}$ cells/well in 96well plates, cultured for $2 \mathrm{~h}$, washed with medium and then cultured for an additional $20 \mathrm{~h}$ in SSC medium in the presence or absence of $1.25 \mu \mathrm{M}, 2.5 \mu \mathrm{M}$ or $5 \mu \mathrm{M}$ WP1066 (A JAK-STAT signalling pathway inhibitor; A4140, APExBIO). SSC viability was detected with CCK8 kit $0 \mathrm{~h}, 4 \mathrm{~h}, 8 \mathrm{~h}, 12 \mathrm{~h}, 16 \mathrm{~h}$ and $20 \mathrm{~h}$ after WP1066 treatment.

\section{Statistical analysis}

The dates are presented as the mean $\pm \mathrm{SD}$, and three independent experiments were repeated at least. The data were analysed using one-way ANOVA in SAS software (SAS Institute Inc., Cary, NC, USA). $P<0.05$ was considered to indicate a statistically significant difference, and $P<0.01$ was considered to indicate a highly significant difference among the different treatment groups.

\section{Results}

Heat shock treatment inhibits SSC proliferation

The CD1 SSC line could be stably cultured in vitro in our laboratory (Fig. 1a). GFR $\alpha-1$ and PLZF are mostly used as consensus markers for SSC identification in rodents [24-26]. Our results also demonstrated that this cell line expressed the SSC surface marker proteins
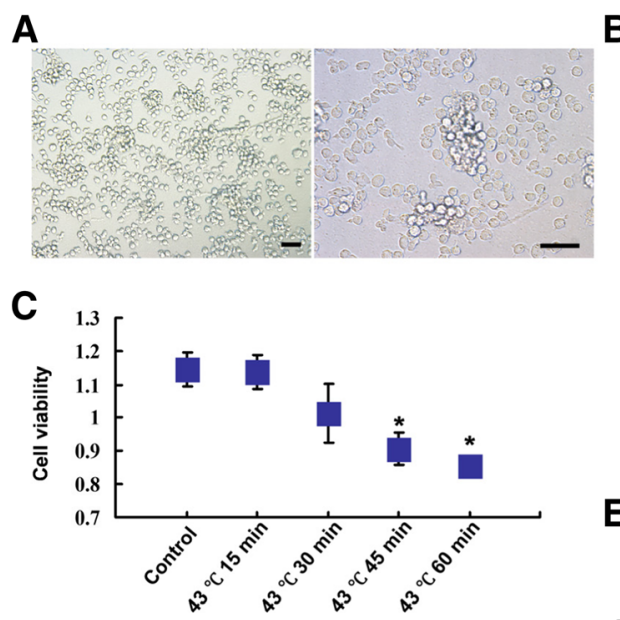

B
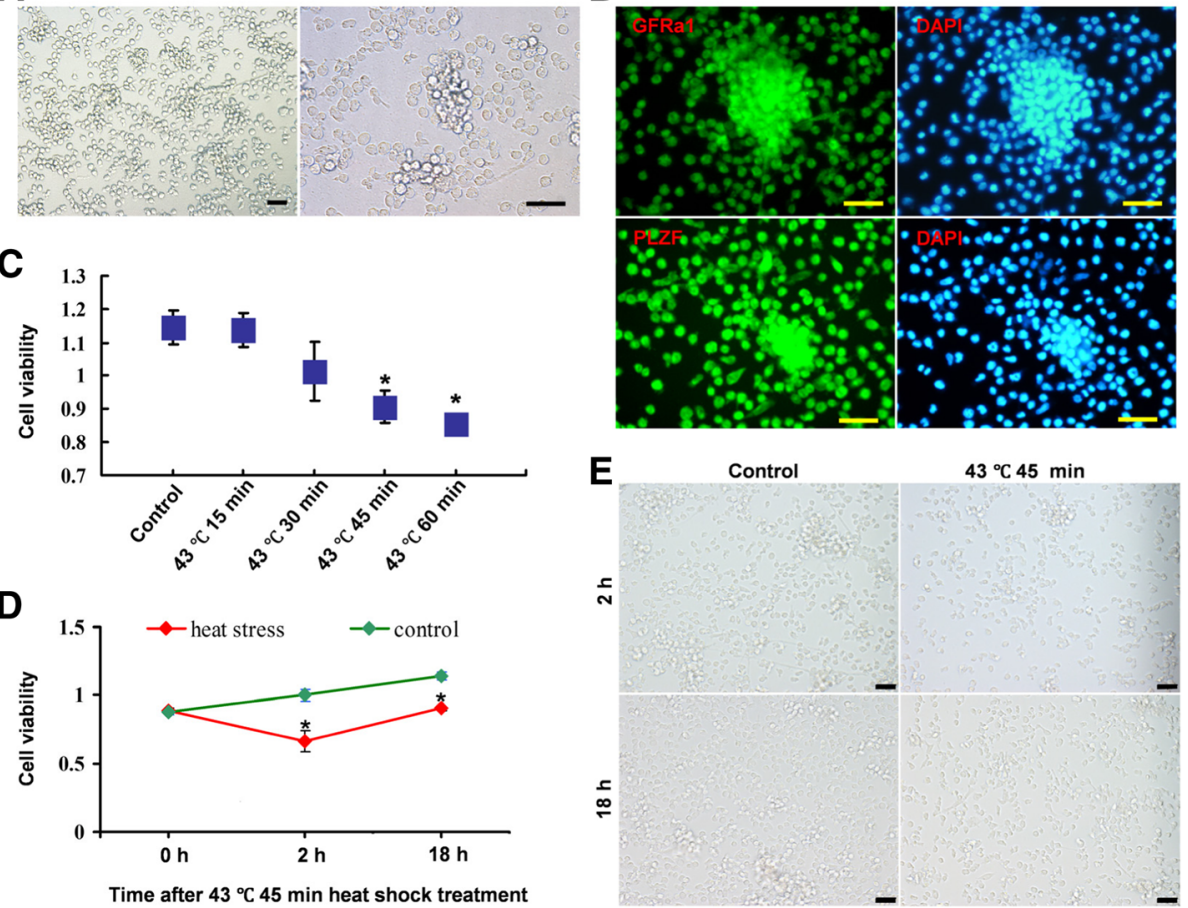

Fig. 1 Heat shock treatment inhibits SSC proliferation. a The CD1 SSC line can be stably cultured in vitro. b The SSC surface marker proteins GFRa-1 and PLZF were expressed in in vitro-cultured SSCS. c Viability of SSCS $18 \mathrm{~h}$ after heat shock treatment. Heat shock treatment at $43^{\circ} \mathrm{C}$ for $45 \mathrm{~min}$ or at $43^{\circ} \mathrm{C}$ for $60 \mathrm{~min}$ significantly inhibited the proliferation of SSCs $18 \mathrm{~h}$ after treatment. $\mathbf{d}$ The viability of SSCs was significantly reduced as early as $2 \mathrm{~h}$ after $45 \mathrm{~min}$ of $43^{\circ} \mathrm{C}$ heat shock treatment. e Two and $18 \mathrm{~h}$ after treatment, compared with the control group, the cell density in the $43^{\circ} \mathrm{C} 45$-min heat shock-treated group was significantly reduced. ${ }^{*} P<0.05$ compared with the control group. Bar $=50 \mu \mathrm{m}$ 
GFR $\alpha-1$ and PLZF during in vitro culture (Fig. 1b). To explore the effects of heat stress on SSCs, we treated them at $43^{\circ} \mathrm{C}$ for $10 \mathrm{~min}, 15 \mathrm{~min}, 30 \mathrm{~min}, 45 \mathrm{~min}$ and 60 min. We found that the heat shock treatment at $43^{\circ} \mathrm{C}$ for $10 \mathrm{~min}, 15 \mathrm{~min}$ or $30 \mathrm{~min}$ had no significant effects on the proliferation of SSCs $18 \mathrm{~h}$ after treatment. However, when the treatment time was extended to $45 \mathrm{~min}$ or $60 \mathrm{~min}$, proliferation was significantly inhibited $(P<$ 0.05) (Fig. 1c). To further clarify the early dynamic changes in the proliferation after heat shock treatment, the viability of in vitro-cultured SSCs was measured at 0 $\mathrm{h}, 2 \mathrm{~h}$ and $18 \mathrm{~h}$ after $45 \mathrm{~min}$ of $43^{\circ} \mathrm{C}$ heat shock treatment. We found that although the proliferative activity remained stable before the treatment, proliferation was significantly reduced as early as $2 \mathrm{~h}$ after the treatment (Fig. 1d). Although there was no significant difference in cell morphology $2 \mathrm{~h}$ after $45 \mathrm{~min}$ of $43^{\circ} \mathrm{C}$ heat shock treatment, cell density was significantly reduced. Eighteen hours after treatment, the number of cells in $45 \mathrm{~min}$ of $43^{\circ} \mathrm{C}$ heat shock-treated group was recovered but was still significantly lower than that in the control group (Fig. 1e). These results indicated that the regulatory mechanism of SSC regeneration was changed $2 \mathrm{~h}$ after the heat shock treatment.

\section{Heat shock treatment did not cause SSCs to undergo apoptosis}

To further clarify whether the proliferation inhibition of SSCs was caused by apoptosis, we investigated the apoptosis of SSCs after heat shock treatment. Our TUNEL test results showed that treatment at $43^{\circ} \mathrm{C}$ for $45 \mathrm{~min}$ or $43^{\circ} \mathrm{C}$ for $60 \mathrm{~min}$ did not cause increased apoptosis of SSCs $2 \mathrm{~h}$ after the heat shock treatment. The numbers of FITC-positive SSCs in the groups treated for $45 \mathrm{~min}$ and $60 \mathrm{~min}$ at $43^{\circ} \mathrm{C}$ were similar to that in the control group $2 \mathrm{~h}$ after the heat shock treatment (Fig. 2a). The Annexin V test results showed that treatment at $43{ }^{\circ} \mathrm{C}$ for 45 min did not cause increased apoptosis of SSC. The percentages of apoptotic cells in the group at $43^{\circ} \mathrm{C}$ for $45 \mathrm{~min}$ and the group treated at $43^{\circ} \mathrm{C}$ for $60 \mathrm{~min}$ were $2.1 \pm 0.14 \%$ and $3.7 \pm 0.85 \% 2 \mathrm{~h}$ after the heat shock treatment, respectively; these values were not significantly different from the value in the control group. Eighteen hours after the heat shock treatment, the SSC apoptosis rate in the group treated at $43{ }^{\circ} \mathrm{C}$ for $45 \mathrm{~min}(2.6 \pm 0.71 \%)$ remained unchanged, while the SSC apoptosis rate in the group treated at $43{ }^{\circ} \mathrm{C}$ for $60 \mathrm{~min}(5.6 \pm 0.42 \%)$ was significantly increased (Fig. 2b). Therefore, in subsequent studies, we treat the in vitro-cultured SSCs at $43^{\circ} \mathrm{C}$ for 45 min and analysed the transcriptome differences between the heat shock-treated group and the control group.
Analysis of differentially expressed genes after heat shock treatment

To explore the gene expression of heat shock-treated SSCs, we performed RNA-Seq analysis on in vitro-cultured SSCs $2 \mathrm{~h}$ after $45 \mathrm{~min}$ of $43^{\circ} \mathrm{C}$ heat shock treatment. In total, 17,822 genes were identified from the heat shock-treated group and control group. We found that the expression of 200 genes changed significantly (with at least a twofold difference between the two groups and an FDR less than 0.05) after the heat shock treatment, among which 173 were upregulated and 27 were downregulated in the heat shock-treated group (Fig. 3).

\section{Gene Ontology analysis of the differentially expressed genes}

Gene Ontology (GO) analysis was used to characterize the functions of the DEGs obtained from RNA-Seq. GO terms can be divided into three categories: the molecular function, biological process and cellular component categories. According to the selected differentially expressed genes, the hypergeometric distributions between the differentially expressed genes and certain (several) specific GO classification terms are calculated. GO analysis will return a $P$ value for each $G O$ term associated with the differentially expressed genes. The top 30 enriched terms are shown in Fig. 3c. The selected top 10 GO enrichment terms were protein folding (e.g. Dnajb1, Dnaja1), chaperone-mediated protein folding (e.g. Clu, Hsph1), positive regulation of tyrosine phosphorylation of STAT protein (e.g. Hes1, Osm), unfolded protein binding (e.g. Serpinh1, Dnajb1), positive regulation of intrinsic apoptotic signalling pathway (e.g. Bbc3, Skil), tyrosine phosphorylation of STAT protein (e.g. Il6ra, Il13), cytokine receptor activity (e.g. Gfra2, Il18r1), response to unfolded protein (e.g. Hsph1, Crebrf), response to heat (e.g. Hsp90aa1, Osm) and regulation of JAKSTAT cascade (e.g. Gfra2, Socs3) (Table 2).

\section{Kyoto Encyclopedia of Genes and Genomes analysis of the differentially expressed genes}

The Kyoto Encyclopedia of Genes and Genomes (KEGG) is a database for systematic analysis of gene function and genome information. KEGG enrichment analysis of differentially expressed genes can reveal pathways with significant enrichment, which is helpful for finding significantly altered biological regulatory pathways. To further explore the roles of the DEGs in SSC proliferation after heat shock treatment, we tested whether the DEGs were enriched in certain KEGG pathways. The statistical results showed that the number of DEGs in environmental information processing pathways was 37 , which was the largest number. Twenty-seven of the 37 genes were involved in the signal transduction pathway, and 19 were associated with 


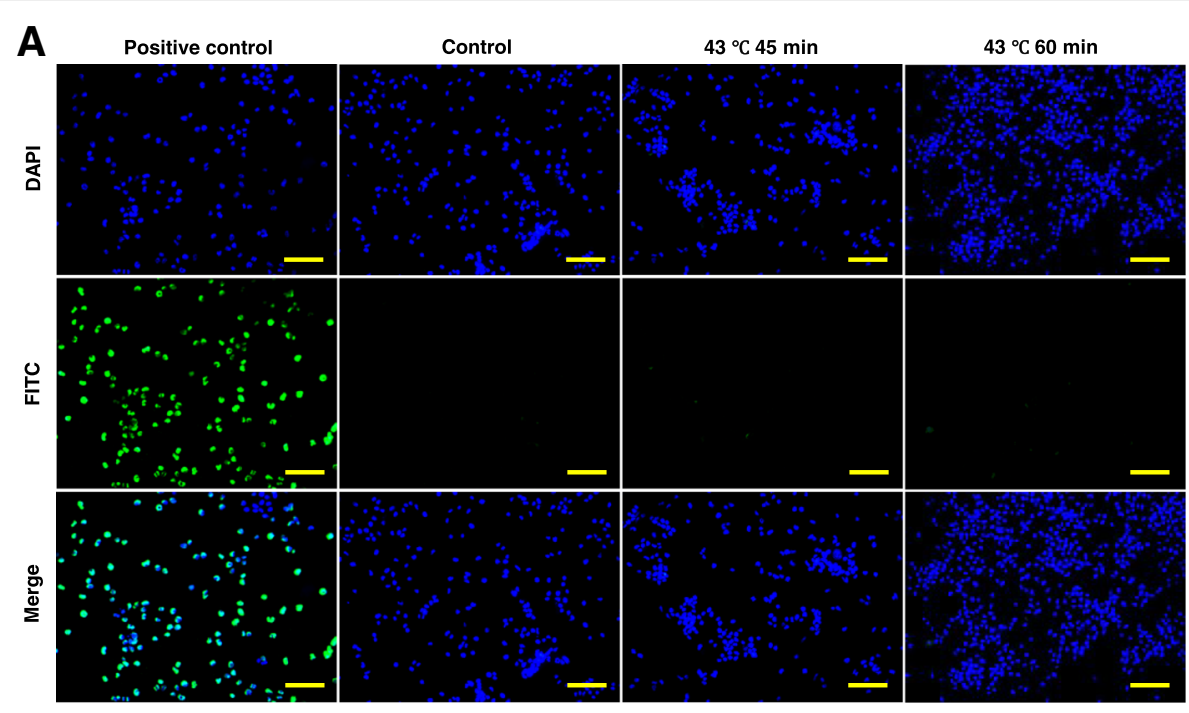

B
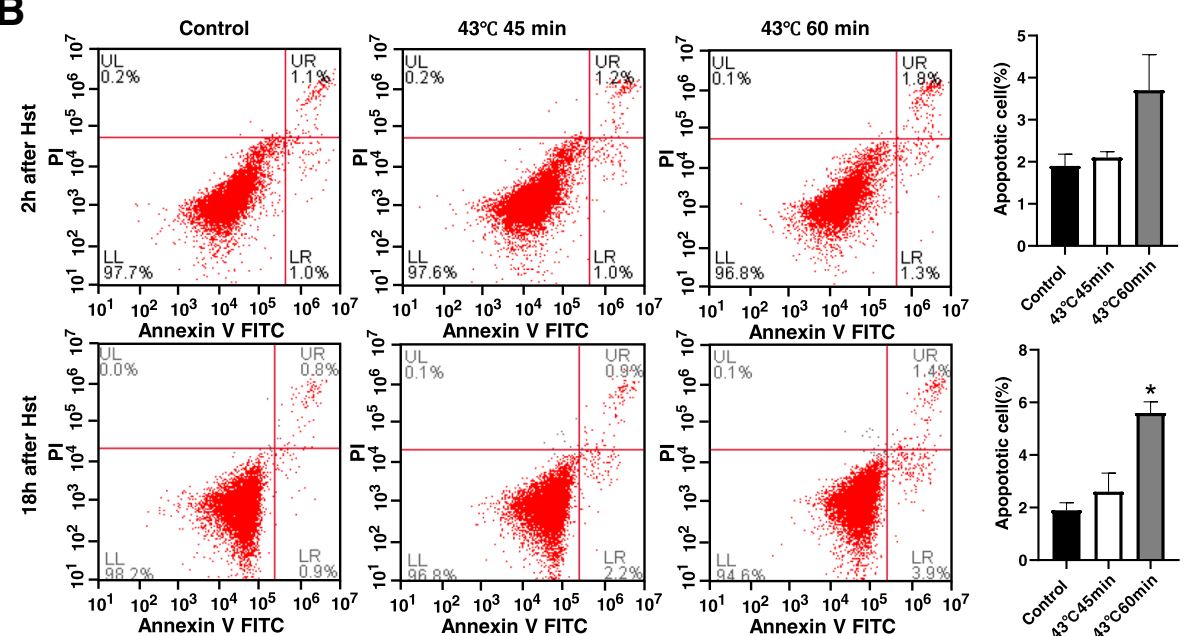

Fig. 2 Heat shock treatment with at $43{ }^{\circ} \mathrm{C}$ for $45 \mathrm{~min}$ did not cause in vitro-cultured SSCs to undergo apoptosis. a The TUNEL test results showed that apoptosis of SSCs was not increased $2 \mathrm{~h}$ after heat shock at $43^{\circ} \mathrm{C}$ for $45 \mathrm{~min}$ or at $43^{\circ} \mathrm{C}$ for $60 \mathrm{~min}$. $\mathbf{b}$ The Annexin $V$ test results showed that $45 \mathrm{~min}$ of $43^{\circ} \mathrm{C}$ heat shock treatment did not cause increased apoptosis of SSCs $2 \mathrm{~h}$ and $18 \mathrm{~h}$ after treatment, while 60 min of $43^{\circ} \mathrm{C}$ heat shock treatment led to increased apoptosis of SSCs $18 \mathrm{~h}$ after heat shock treatment. Bar $=200 \mu \mathrm{m}$

signalling molecules and interaction pathways. The numbers of DEGs associated with organismal systems pathways, metabolism, cellular processes and genetic information processing were $32,14,13$ and 11 , respectively (Fig. 4a). The top 30 signalling pathways that were enriched in the heat shock-treated group versus the control group are shown in Fig. 4b. Moreover, we screened 10 signalling pathways on the basis of our research purposes and cell phenotypes. These DEGs were significantly enriched for the estrogen signalling pathway, the TNF signalling pathway, protein processing in the endoplasmic reticulum, cytokine-cytokine receptor interaction, the JAK-STAT signalling pathway, ECM-receptor interaction, spliceosomes, apoptosis, the PI3K-Akt signalling pathway and MAPK the signalling pathway (Table 3).
JAK-STAT signalling pathway and S phase cell cycle arrest of SSCS

To verify the results of RNA-Seq in the JAK-STAT signalling pathway, we selected DEGs in the JAKSTAT signalling pathway (Fig. 5a) and validated the gene expression levels by qRT-PCR. We found that the Osm, Socs3, Il6ra and Il13 genes were significantly upregulated (Fig. 5b). Upregulation of these genes in the JAK-STAT signalling pathway may prevent cell cycle progression. Therefore, we studied the changes in the cell cycle in SSCs $2 \mathrm{~h}$ and $18 \mathrm{~h}$ after $45 \mathrm{~min}$ of $43^{\circ} \mathrm{C}$ heat shock treatment. The results showed that the proportion of cells in the S stage increased from $63.79 \pm 1.59 \%$ before treatment to $73.19 \pm 0.92 \% 2 \mathrm{~h}$ after treatment. Eighteen hours 
A

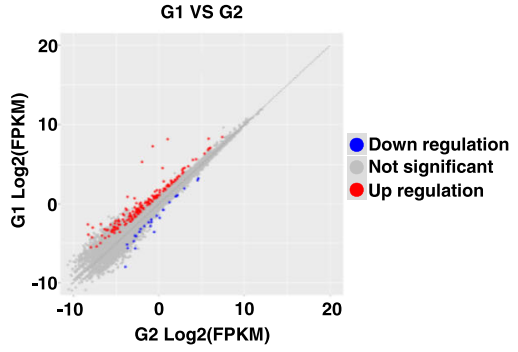

B

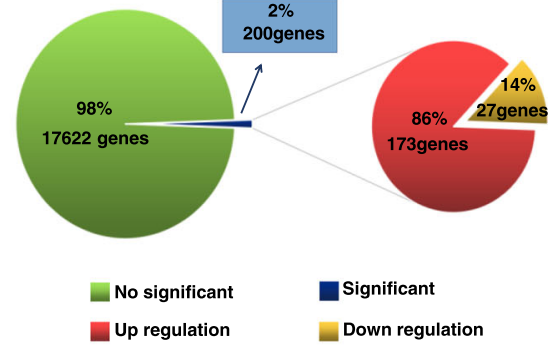

Up regulation

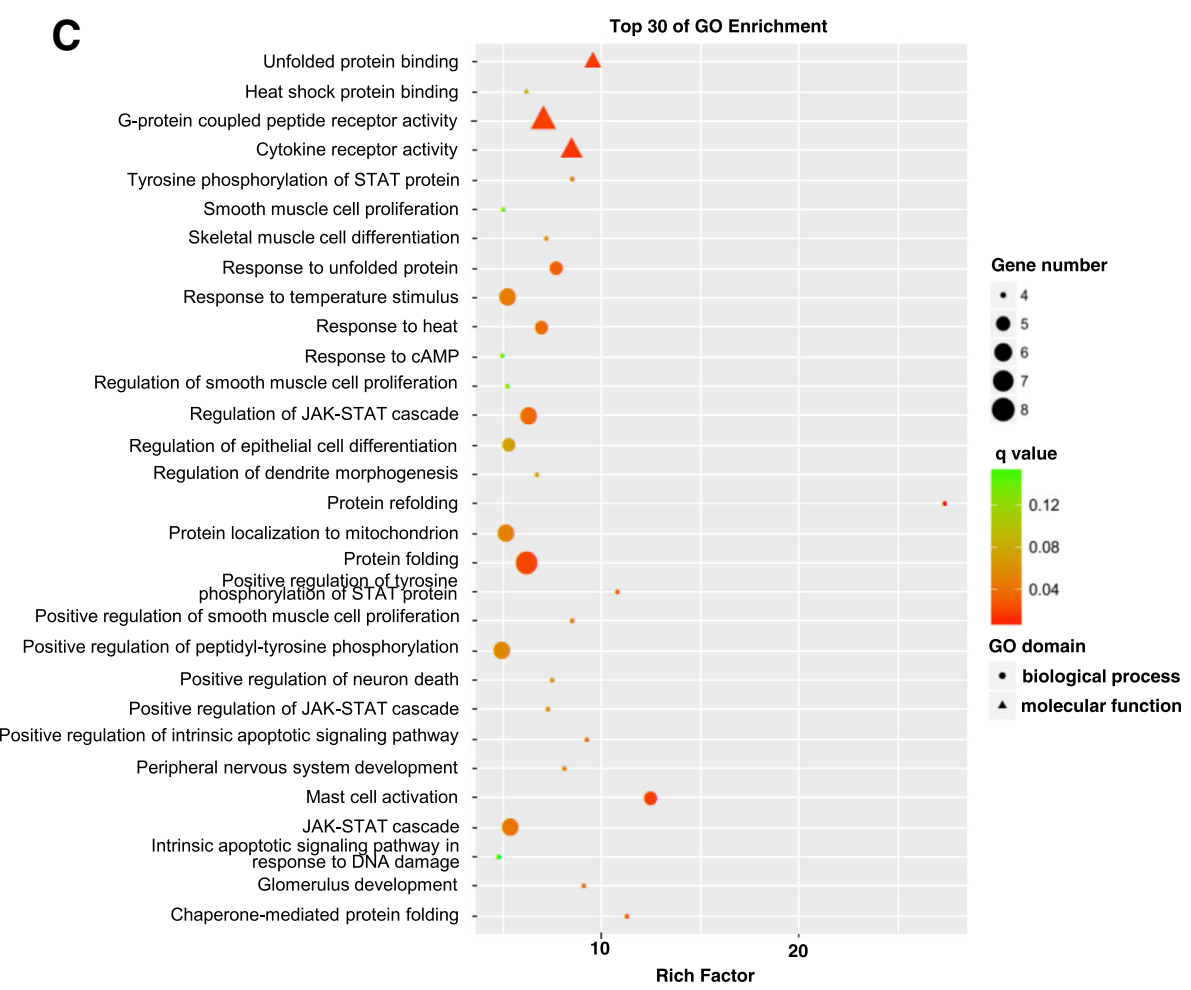

Fig. 3 Analysis of the differentially expressed genes after heat shock treatment. a Scatter diagram of gene expression in the heat shock-treated group. Red indicates upregulated genes, and blue indicates downregulated genes. $\mathbf{b}$ Pie chart representation of the percentages of genes that were significantly upregulated and downregulated in the control and treated groups. c Top 30 enrichment GO terms obtained through GO analysis of the differentially expressed genes

after the heat shock treatment, there was no significant difference in the $\mathrm{S}$ phase cell proportion between the group treated at $43{ }^{\circ} \mathrm{C}$ for $45 \mathrm{~min}(62.32 \pm$ $1.68 \%$ ) and the control group (Fig. 5c). These results indicated that the SSCs showed short-term S phase arrest after the heat shock treatment.

To further clarify whether the JAK-STAT pathway was involved in the inhibition of SSC self-renewal caused by heat shock treatment, we detected the expression and phosphorylation of some proteins in the JAK-STAT pathway. We found that the expression of Socs3 protein increased and the phosphorylation of STAT3 decreased after the heat shock treatment(Fig. 6a), indicating that the JAK-STAT pathway was inhibited. Our bioinformatics analysis results showed that the PI3K/Akt pathway was the downstream signalling pathway of the JAK-STAT pathway in this study(Fig. 5a), and our experimental results also showed that the phosphorylation of Akt decreased after the heat shock treatment (Fig. 6a). To further verify the function of the JAK-STAT pathway, we blocked the JAK-STAT pathway with the inhibitor WP1066 in in vitro-cultured SSCs and found that SSC self-renewal was inhibited (Fig. 6a), indicating that the JAK-STAT pathway promotes SSC self-renewal. Based on these studies, we found that the JAK-STAT pathway is involved in the inhibition of SSC self-renewal after heat shock treatment. 


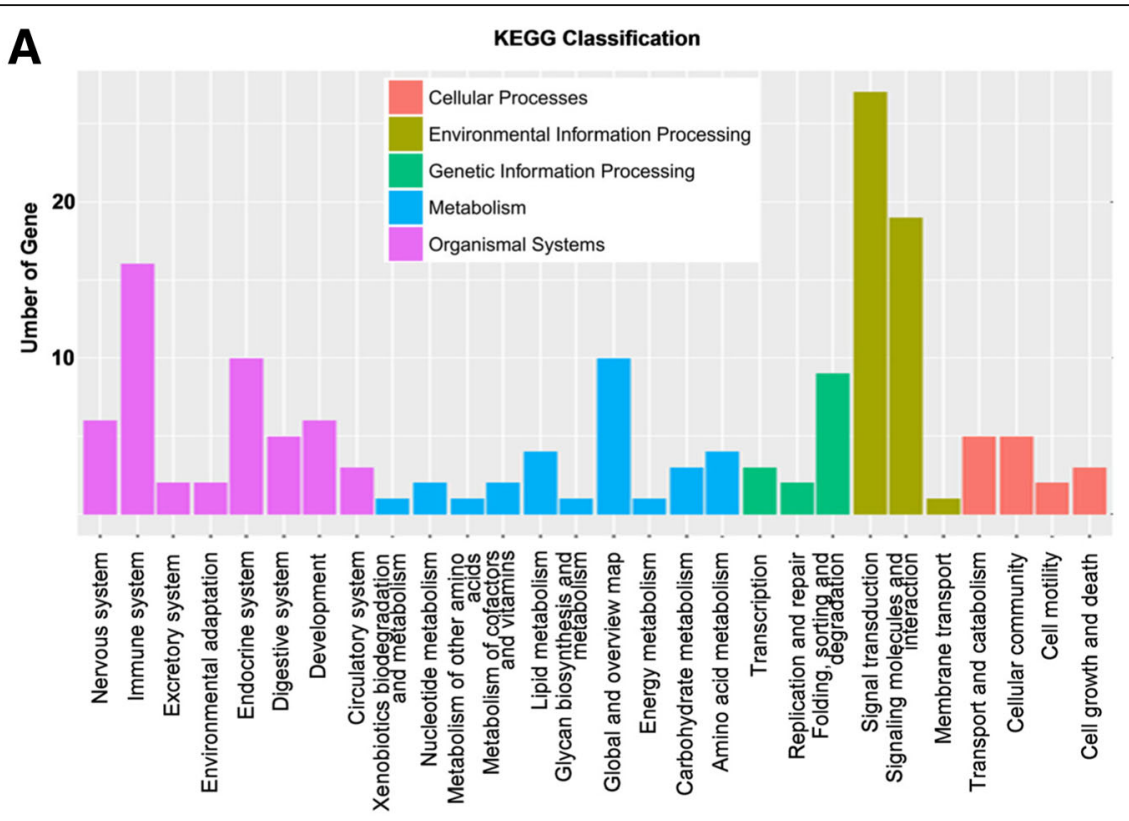

B

Top 30 of Pathway Enrichment

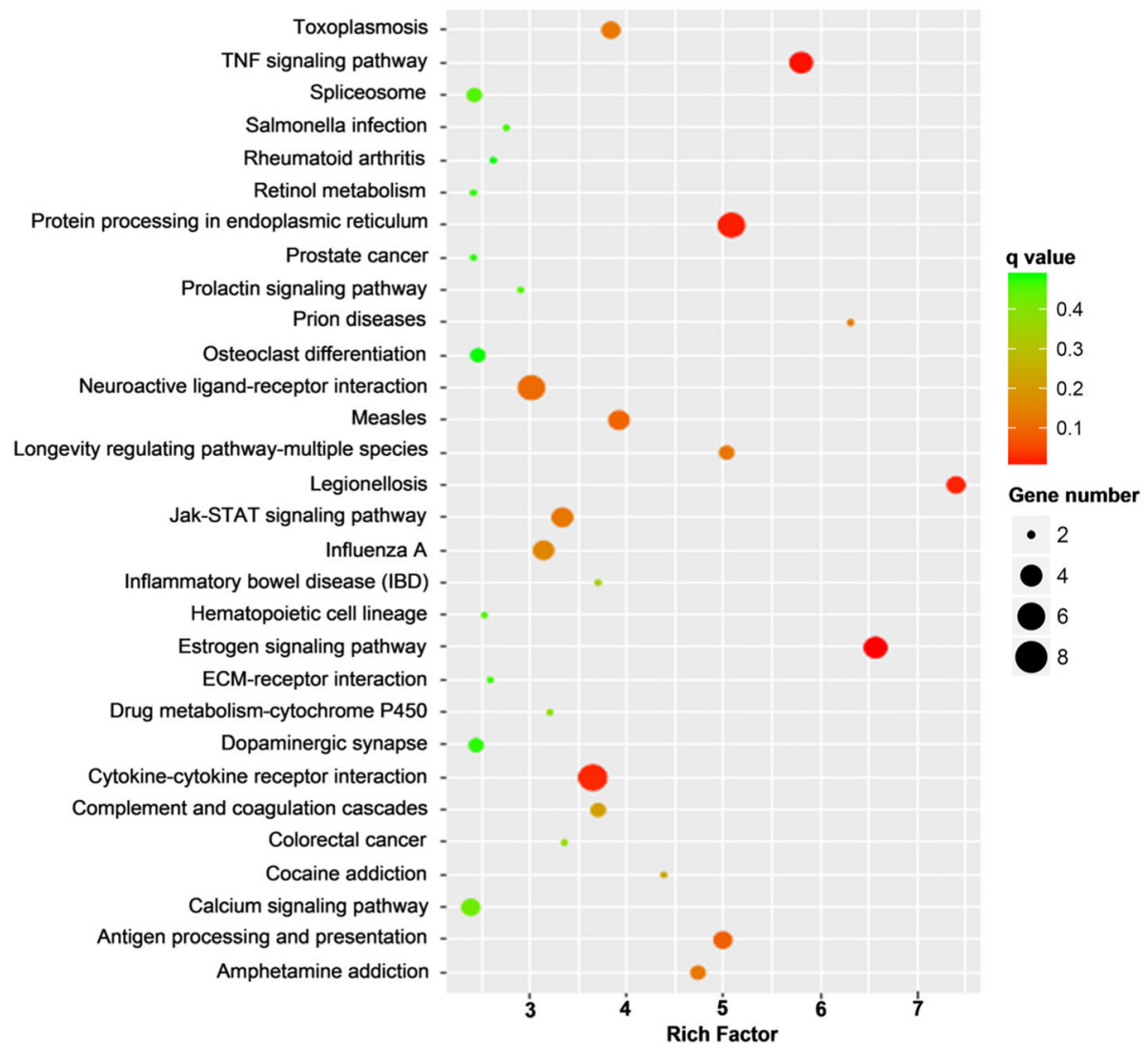

Fig. 4 KEGG pathway analysis of the differentially expressed genes (DEGs). a KEGG classification. b Top 30 enriched pathways

\section{Discussion}

In this study, for the first time, we studied the developmental potential and overall gene expression patterns of in vitro-cultured SSCs after heat shock treatment.
Previous research has shown that heat shock treatment induces adverse effects in the testes of mice, rats and cows, including germ cell apoptosis, low-quality sperm and abnormal DNA and chromatin structures [27-29]. 
Table 2 Selected top 10 of GO enrichment

\begin{tabular}{|c|c|c|c|c|c|}
\hline GO-ID & GO term & Type & Up-genes & $\begin{array}{l}\text { Down- } \\
\text { genes }\end{array}$ & $P$ value \\
\hline $\begin{array}{l}\text { GO: } \\
0042026\end{array}$ & Protein refolding & $\begin{array}{l}\text { Biological } \\
\text { process }\end{array}$ & Dnajb1, Dnaja1, Hspa1l, Hsp90aa1 & - & $\begin{array}{l}1.96 \mathrm{E} \\
-06\end{array}$ \\
\hline $\begin{array}{l}\text { GO: } \\
0061077\end{array}$ & Chaperone-mediated protein folding & $\begin{array}{l}\text { Biological } \\
\text { process }\end{array}$ & Clu, Hsph1, Dnajb1, Unc45b & - & $\begin{array}{l}9.11 \mathrm{E} \\
-05\end{array}$ \\
\hline $\begin{array}{l}\text { GO: } \\
0042531\end{array}$ & $\begin{array}{l}\text { Positive regulation of tyrosine phosphorylation of STAT } \\
\text { protein }\end{array}$ & $\begin{array}{l}\text { Biological } \\
\text { process }\end{array}$ & Hes1, Osm, Il6ra, II13 & - & 0.00011 \\
\hline $\begin{array}{l}\text { GO: } \\
0051082\end{array}$ & Unfolded protein binding & $\begin{array}{l}\text { Molecular } \\
\text { function }\end{array}$ & $\begin{array}{l}\text { Serpinh1, Dnajb1, Hsp90aa1, Dnaja1, } \\
\text { Hspa1l }\end{array}$ & - & $\begin{array}{l}4.71 \mathrm{E} \\
-05\end{array}$ \\
\hline $\begin{array}{l}\text { GO: } \\
2001244\end{array}$ & $\begin{array}{l}\text { Positive regulation of intrinsic apoptotic signaling } \\
\text { pathway }\end{array}$ & $\begin{array}{l}\text { Biological } \\
\text { process }\end{array}$ & Bbc3, Skil, Clu, Bcl2l11 & - & 0.00022 \\
\hline $\begin{array}{l}\text { GO: } \\
0007260\end{array}$ & Tyrosine phosphorylation of STAT protein & $\begin{array}{l}\text { Biological } \\
\text { process }\end{array}$ & ॥6ra, II13, Osm, Hes1 & - & 0.00032 \\
\hline $\begin{array}{l}\text { GO: } \\
0004896\end{array}$ & Cytokine receptor activity & $\begin{array}{l}\text { Molecular } \\
\text { function }\end{array}$ & Gfra2, II18r1, Ccr4, II1rl1, Ccr9, II6ra & - & $\begin{array}{l}2.44 \mathrm{E} \\
-05\end{array}$ \\
\hline $\begin{array}{l}\text { GO: } \\
0006986\end{array}$ & Response to unfolded protein & $\begin{array}{l}\text { Biological } \\
\text { process }\end{array}$ & Hsph1, Crebrf, Hsp90aa1, Hspa4l & Chac1 & 0.00014 \\
\hline $\begin{array}{l}\text { GO: } \\
0009408\end{array}$ & Response to heat & $\begin{array}{l}\text { Biological } \\
\text { process }\end{array}$ & $\begin{array}{l}\text { Hsp90aa1, Osm, Socs3, Trp53inp1, } \\
\text { Dnaja1 }\end{array}$ & - & 0.00024 \\
\hline $\begin{array}{l}\text { GO: } \\
0046425\end{array}$ & Regulation of JAK-STAT cascade & $\begin{array}{l}\text { Biological } \\
\text { process }\end{array}$ & Gfra2, Socs3, I113, Il6ra, Osm, Hes1 & - & 0.00014 \\
\hline
\end{tabular}

However, the effects of heat shock treatment on SSC development were not fully understood. In this study, we found that high temperature suppressed SSC self-renewal through $\mathrm{S}$ phase cell cycle arrest but not apoptosis. These results provide new insights for the diagnosis and treatment of human asthenospermia associated with high temperature.

We conducted experiments on the effects of high temperature on the development of the in vitro-cultured SSC cell line CD-1. The main limitation of in vivo SSC research is that the number of SSCs in vivo is very small. Usually, SSCs account for as few as $0.03 \%$ of all adult testis cells [19]. It is thus difficult to detect the influence of high temperature on SSC development and gene expression in vivo. However, the use of SSC cell lines in this study overcame this limitation. The CD-1 SSC cell line cultured in our laboratory stably expressed PLZF and Gfra-1 protein. PLZF and Gfra-1 are mostly used as consensus markers for SSC identification in rodents [30]. PLZF, a transcription-inhibiting protein, is expressed in the nuclei of A single (As), A paired (Apr) and A aligned (Aal) spermatogonia and is an essential autocrine signalling protein for SSC self-renewal [31]. GFRa1 is a receptor of glial cell line-derived neurotrophic factor (GDNF). GFRa1 is expressed in As, Apr and Aal4 spermatogonia in mice [26]. Thus, in this study, we used the CD-1 SSC line to detect the effects of heat shock treatment on SSC proliferation.

We established a stable heat shock treatment scheme for in vitro-cultured SSCs. In our previous experiment, we treated the testes with a single heat shock treatment in a hot water bath at $43^{\circ} \mathrm{C}$ for $15 \mathrm{~min}[9,32]$. Therefore, in this study, we treated SSCs cultured in vitro at $43^{\circ} \mathrm{C}$ in a $\mathrm{CO}_{2}$ incubator for different times, including $10 \mathrm{~min}$, $15 \mathrm{~min}, 30 \mathrm{~min}, 45 \mathrm{~min}$ and $60 \mathrm{~min}$. We found that heat shock treatment at $43{ }^{\circ} \mathrm{C}$ for $45 \mathrm{~min}$ or $60 \mathrm{~min}$ significantly inhibited the proliferation of SSCs cultured in vitro. However, it remains unclear whether the SSC proliferation inhibition was caused by the inhibition of stem cell self-renewal or by apoptosis. Some researchers have found that $15 \mathrm{~min}$ of testicular heat shock treatment at $43^{\circ} \mathrm{C}$ can induce differentiated germ cell apoptosis [33, 34]. Therefore, in this study, we also studied the effect of heat shock treatment on in vitro-cultured SSC apoptosis. Our results showed that treatment at $43^{\circ} \mathrm{C}$ for 45 min or at $43^{\circ} \mathrm{C}$ for $60 \mathrm{~min}$ did not cause increased apoptosis of SSCs, indicating that the inhibition of SSC proliferation was caused by the inhibition of SSC self-renewal rather than by apoptosis.

We performed RNA-Seq analysis of in vitro-cultured SSCs after the heat shock treatment and found 200 DEGs. The DEGs were screened by GO and KEGG analyses, and these genes were found to affect protein folding, protein localization and some types of cellular signalling. The RNA sequencing results showed that there were no GO terms associated with self-renewal or cell cycle arrest. However, we found that there were many GO terms related to the JAK-STAT signalling pathway. The JAK/STAT signalling pathway is a common pathway through which various cytokines and growth factors transmit signals in cells, mediating cell 


\section{A}

JAK-STAT SIGNALING PATHWAY

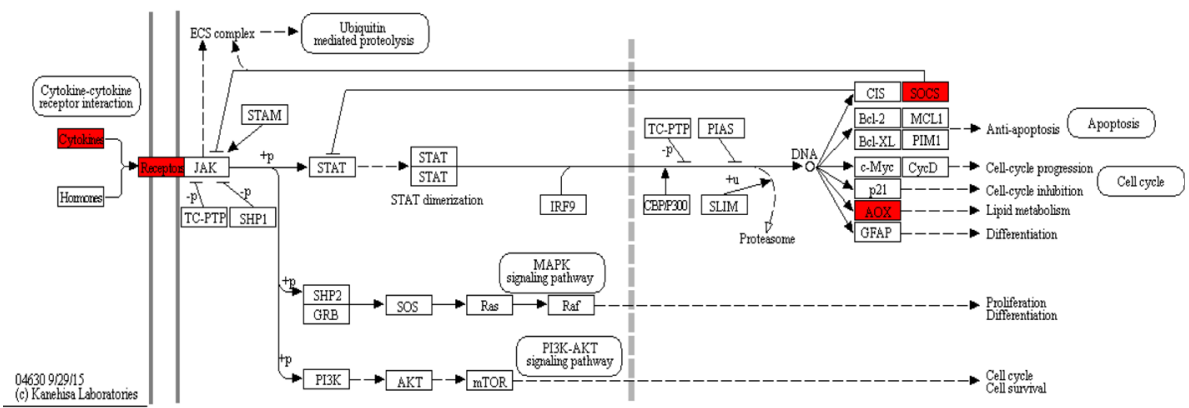

B
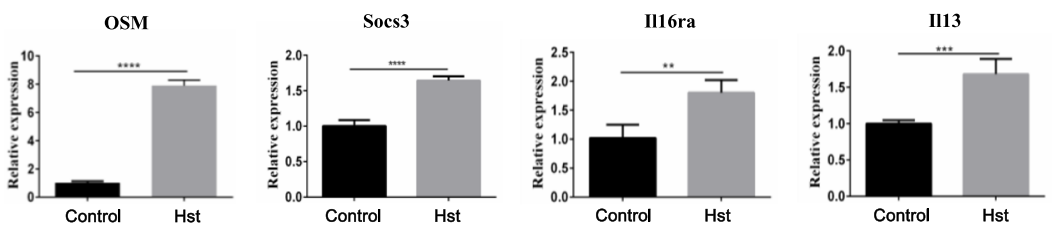

C
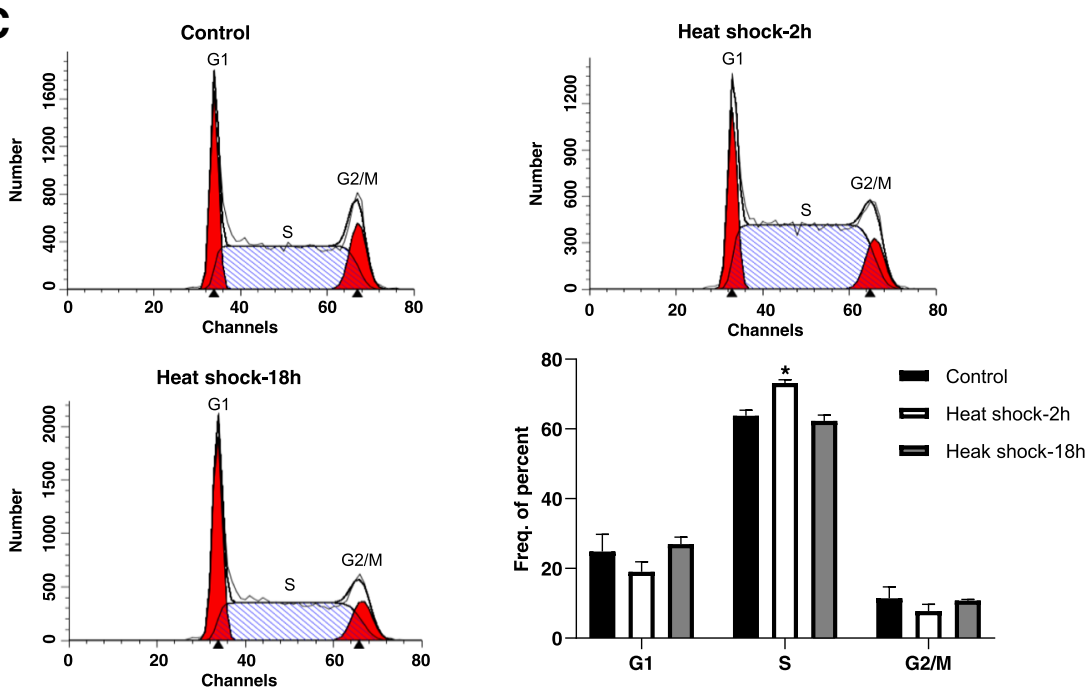

Fig. 5 Heat shock treatment-induced SSC cell cycle inhibition. a The KEGG JAK-STAT signalling pathway responds to cell cycle progression and inhibition; the genes highlighted in red were enriched and upregulated. $\mathbf{b}$ Validation of the enriched and upregulated genes in the Jak-Stat signalling pathway by quantitative PCR. c Heat shock treatment-mediated S phase cell cycle arrest in in vitro-cultured SSCs $2 \mathrm{~h}$ after heat shock treatment. However, $18 \mathrm{~h}$ after heat shock treatment, $\mathrm{S}$ phase cycle arrest was eliminated, and the proportion of cells in S phase returned to a normal level

proliferation, differentiation, migration and apoptosis [35]. Osm, Il6ra, Il13 and Socs3 were enriched in the JAK/STAT signalling pathway, and these genes were upregulated significantly. Osm is a member of the IL-6 family and is a secretory factor and cell growth regulator. It has been reported in the literature that in A375 melanoma cells, Osm can upregulate P27 through a STAT1-dependent cellular pathway to inhibit cell proliferation [36]. In breast cancer, Osm can downregulate CMyc and upregulate P21 and P53 through the JAK/ STATs signalling pathway to inhibit the growth of cancer cells $[37,38]$. Il6ra, a subunit encoding the interleukin 6 (IL6) receptor complex, is also a receptor subunit shared by other cytokines. Both IL- 6 and Osm have been reported to inhibit MCF-7 cell growth in breast cancer [39]. Our bioinformatics analysis results showed that Socs3 was one of the upregulated genes; this gene can inhibit the JAK-STAT pathway and then the PI3K-Akt pathway through negative feedback. We confirmed that the expression of Socs3 protein was increased and that the phosphorylation of STAT3 was decreased in this study, indicating that SSC self-renewal may have been 

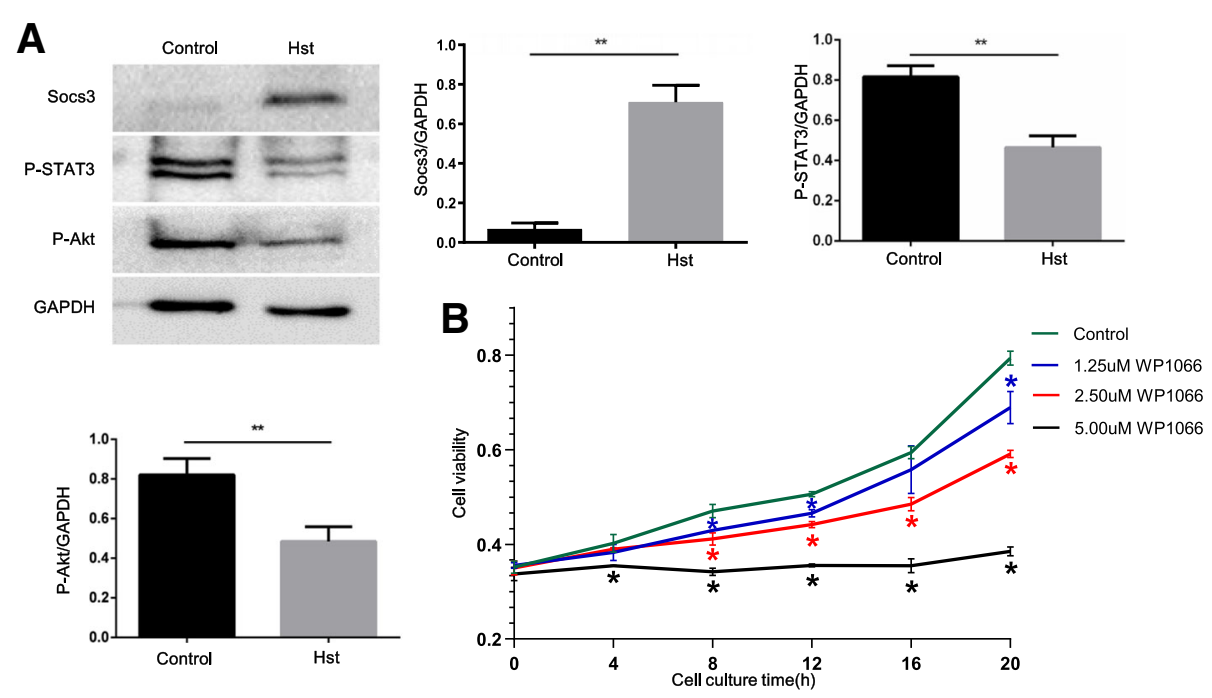

Fig. 6 The JAK-STAT signalling pathway is involved in the inhibition of spermatogonial stem cell regeneration induced by high temperature. a The expression of the negative feedback inhibitor Socs 3 in the JAK-STAT signalling pathway was upregulated $2 \mathrm{~h}$ after heat shock treatment, while the phosphorylation of STAT3 was reduced. The phosphorylation of Akt in the PI3K-Akt signalling pathway, which was regulated by the JAK-STAT signalling pathway, was found to be reduced. $\mathbf{b}$ Inhibition of the JAK/STAT signalling pathway by WP1066 in non-treated SSCs induced a decrease in proliferation. The asterisk indicates a significant difference from the control group

inhibited through the JAK-STAT pathway after heat shock treatment. It has been reported that Stat3 is not required for the self-renewal of spermatogonial stem cells but rather is needed for spermatogonial differentiation in mice [40]. However, the role of the JAK-STAT pathway in SSC self-renewal under stress conditions remains unclear [41]. In the Drosophila male germline, local activation of the Janus kinase-signal transducer and activator of transcription (Jak-STAT) pathway maintains stem cells, and germline stem cells lacking Jak-STAT signalling differentiate into spermatogonia without self-renewal [42], and JAK-STAT signalling regulation is also associated with chicken embryonic stem cell differentiation into male germ cells [43]. Our study showed that JAK/STAT signalling is also involved in this process during stress in in vitro-cultured SSCs.

Table 3 Selected top 10 of KEGG pathway enrichment

\begin{tabular}{|c|c|c|c|c|}
\hline Pathway ID & KEGG pathway & Up-genes & $\begin{array}{l}\text { Down- } \\
\text { genes }\end{array}$ & $P$ value \\
\hline mmu04915 & Estrogen signaling pathway & Hsp90aa1, Hspa1l, Fos, Hspa1a, Creb5, Hspa1b & - & $\begin{array}{l}1.29 E \\
-04\end{array}$ \\
\hline mmu04668 & TNF signaling pathway & Fos, Creb5, Socs3, Cxcl3, Il18r1, Csf1 & - & $\begin{array}{l}2.74 \mathrm{E} \\
-04\end{array}$ \\
\hline mmu04141 & $\begin{array}{l}\text { Protein processing in endoplasmic } \\
\text { reticulum }\end{array}$ & $\begin{array}{l}\text { Hspa4l, Hsp90aa1, Hspa1l, Hsph1, Hspa1a, Dnaja1, Dnajb1, } \\
\text { Hspa1b }\end{array}$ & - & $\begin{array}{l}1.24 \mathrm{E} \\
-04\end{array}$ \\
\hline mmu04060 & Cytokine-cytokine receptor interaction & Ccr9, Osm, Tnfrsf19, Inhbe, Ccr4, II6ra, I18r1, II13, Csf1 & - & $\begin{array}{l}7.87 \mathrm{E} \\
-04\end{array}$ \\
\hline mmu04630 & Jak-STAT signaling pathway & Osm, Aox1, Socs3, I16ra, $\| 13$ & - & $\begin{array}{l}1.07 E \\
-02\end{array}$ \\
\hline mmu04512 & ECM-receptor interaction & Itgb4, Sv2c & - & $\begin{array}{l}9.24 \mathrm{E} \\
-02\end{array}$ \\
\hline mmu03040 & Spliceosome & Hspa1l, Hspa1a, Hspa1b & - & $\begin{array}{l}8.08 \mathrm{E} \\
-02\end{array}$ \\
\hline mmu04210 & Apoptosis & $\mathrm{Bcl} 2111, \mathrm{Bbc} 3$, Fos & - & $\begin{array}{l}9.22 \mathrm{E} \\
-02\end{array}$ \\
\hline mmu04151 & PI3K-Akt signaling pathway & Bcl2l11, Itgb4, Hsp90aa1, Osm, Creb5, Il6ra, Csf1 & - & $\begin{array}{l}4.24 \mathrm{E} \\
-02\end{array}$ \\
\hline mmu04010 & MAPK signaling pathway & Hspa1l, Fos, Hspa1a, Hspa1b & - & $\begin{array}{l}1.96 \mathrm{E} \\
-01\end{array}$ \\
\hline
\end{tabular}


In addition, Osm was also enriched in the PI3K-AKt signalling pathway. In breast cancer, Osm can inhibit cancer cell growth by upregulating the P53 tumour suppressor gene. As a tumour suppressor gene, P53 functions to induce cell growth arrest, apoptosis, cell differentiation and DNA repair by the PI3K-AKt signalling pathway [44]. In our experiments, SSCs exhibited upregulation of the P53 signalling pathway-related genes Bbc3, Trp53inp1 and Trp53cor1 after heat stress. P53 can inhibit the proliferation of SSCs by activating the target genes Bbc3, Trp53inp1 and Trp53cor1 and inducing cell cycle arrest or apoptosis. Our findings suggest that the P53 signalling pathway may play an important role in the growth inhibition process of SSCs after high stress. In the PI3K/AKt signalling pathway, Akt can bind to MDM2 to phosphorylate its Ser166 and Ser186 sites and induce nuclear import or upregulate ubiquitin ligase activity, thereby promoting P53 inactivation or degradation and blocking P53-mediated transcription reaction $[45,46]$. Our results showed that phosphorylated Akt expression was reduced in this study. Therefore, we hypothesized that Osm may act as a negative feedback regulator of the PI3K/AKt signalling pathway or induce a negative feedback regulator of the PI3K/AKt signalling pathway through the JAK/STAT signalling pathway, thereby mediating the inhibition of growth through the P53 signalling pathway after heat stress. Our results also showed a significant $\mathrm{S}$ phase arrest of SSCs after heat shock treatment. This result further indicates that the JAK/STAT and PI3K/AKt signalling pathways play important roles in SSC cycle arrest.

\section{Conclusion}

Our results showed that heat shock treatment at $43{ }^{\circ} \mathrm{C}$ for $45 \mathrm{~min}$ significantly inhibited SSC proliferation through $\mathrm{S}$ phase cell cycle arrest but not apoptosis. We also screened some key genes involved in the cell proliferating signalling pathways by RNA-Seq. These results provide an important reference for subsequent study of the key genes in the molecular regulation mechanism of SSC self-renewal under heat shock treatment. At the same time, our findings also provide a reference for further study of the pathogenesis of male infertility caused by high temperature.

\footnotetext{
Abbreviations

Aal: A aligned; Apr: A paired; As: A single; bFGF: Basic fibroblast growth factor; DAVID: Visualization and Integrated Discovery; DEGs: Differentially expressed genes; FBS: Foetal calf serum; GDNF: Glial cell line-derived neurotrophic factor; GO: Gene Ontology; Hst: Heat shock treatment; IL6: Interleukin 6; MAPK: Mitogen-activated protein kinase; Osm: Oncostain M; ROS: Reactive oxygen species; SSCs: Spermatogonial stem cells
}

\section{Acknowledgements}

The authors would like to thank professor Wu Ji from Shanghai Jiao Tong University for her donation of the CD1 SSCs cell line.

\section{Authors' contributions}

JW, GWJ and LX were responsible for the experiments, data analysis and editing of the manuscript. JH and DSL participated in the design of the study and edited the manuscript. MWZ contributed to the conception, supervision, design and editing of the manuscript. All authors read and approved the final manuscript.

\section{Funding}

This work was supported by the National Natural Science Foundation of China (81460488, 81860266), the Key Research and Development Program of Ningxia Hui Autonomous Region (2016KJHM43) and Ningxia High School first-class Disciplines (West China first-class Disciplines Basic Medical Sciences at Ningxia Medical University) (NXYLXK2017B07).

\section{Availability of data and materials}

Please contact the corresponding authors for data requests.

\section{Ethics approval and consent to participate}

The experiments using mice were approved by the ethics committee of Ningxia Medical University, and all animal care and experiments were carried out in accordance with the institutional ethical guidelines for animal experiments.

\section{Consent for publication}

Not applicable

\section{Competing interests}

The authors declare that they have no competing interests.

\section{Author details}

${ }^{1}$ Key Laboratory of Fertility Preservation and Maintenance of Ministry of Education, and Key Laboratory of Reproduction and Genetics of Ningxia Hui Autonomous Region, Department of Anatomy, Histology and Embryology, School of Basic Medical Science, Ningxia Medical University, Yinchuan 750004, China. ${ }^{2}$ CAS Key Laboratory of Genome Sciences and Information, Beijing Institute of Genomics, Chinese Academy of Sciences, Beijing 100101, China. ${ }^{3}$ Center for Reproductive Biology and Health, College of Agricultural Sciences, The Pennsylvania State University, University Park, PA 16802, USA.

Received: 8 February 2019 Revised: 1 July 2019

Accepted: 11 July 2019 Published online: 29 July 2019

\section{References}

1. Schlegel PN. Evaluation of male infertility. Minerva Ginecol. 2009;61:261-83.

2. Brito LF, Silva AE, Barbosa RT, Kastelic JP. Testicular thermoregulation in Bos indicus, crossbred and Bos taurus bulls: relationship with scrotal, testicular vascular cone and testicular morphology, and effects on semen quality and sperm production. Theriogenology. 2004;61:511-28.

3. Hutson JM, Hasthorpe S, Heyns CF. Anatomical and functional aspects of testicular descent and cryptorchidism. Endocr Rev. 1997;18:259-80.

4. Zivkovic D, Varga J, Konstantinidis G, Vlaski J, Snyder HM, Hadziselimovic F. Regional differences in maturation of germ cells of cryptorchid testes: role of environment. Acta Paediatr. 2009;98:1339-43.

5. Kamisawa H, Kojima Y, Mizuno K, Imura M, Hayashi Y, Kohri K. Attenuation of spermatogonial stem cell activity in cryptorchid testes. J Urol. 2012;187:1047-52.

6. Morgentaler A, Stahl BC, Yin Y. Testis and temperature: an historical, clinical, and research perspective. J Androl. 1999;20:189-95.

7. Kanter M, Aktas C, Erboga M. Heat stress decreases testicular germ cell proliferation and increases apoptosis in short term: an immunohistochemical and ultrastructural study. Toxicol Ind Health. 2013;29:99-113.

8. Ishikawa T, Kondo Y, Goda K, Fujisawa M. Overexpression of endothelial nitric oxide synthase in transgenic mice accelerates testicular germ cell apoptosis induced by experimental cryptorchidism. J Androl. 2005;26:281-8.

9. Ma W, An L, Wu Z, Wang X, Guo M, Miao K, Ma W, Tian J. Efficient and safe recipient preparation for transplantation of mouse spermatogonial stem cells: pretreating testes with heat shock. Biol Reprod. 2011;85:670-7.

10. Salces-Ortiz J, Ramon M, Gonzalez C, Perez-Guzman MD, Garde JJ, GarciaAlvarez O, Maroto-Morales A, Calvo JH, Serrano MM. Differences in the ovine HSP90AA1 gene expression rates caused by two linked 
polymorphisms at its promoter affect rams sperm DNA fragmentation under environmental heat stress conditions. PLoS One. 2015;10:e0116360.

11. Hamilton T, Siqueira AFP, de Castro LS, Mendes CM, Delgado JC, de Assis PM, Mesquita LP, Maiorka PC, Nichi M, Goissis MD, Visintin JA, Assumpcao M. Effect of heat stress on sperm DNA: protamine assessment in ram spermatozoa and testicle. Oxidative Med Cell Longev. 2018;2018:5413056.

12. Houston BJ, Nixon B, Martin JH, De luliis GN, Trigg NA, Bromfield EG, McEwan KE, Aitken RJ. Heat exposure induces oxidative stress and DNA damage in the male germ line. Biol Reprod. 2018;98:593-606.

13. Erfani Majd N, Sadeghi N, Tavalaee M, Tabandeh MR, Nasr-Esfahani MH. Evaluation of oxidative stress in testis and sperm of rat following induced varicocele. Urol J. 2019;16:300-306.

14. Paul C, Melton DW, Saunders PT. Do heat stress and deficits in DNA repair pathways have a negative impact on male fertility? Mol Hum Reprod. 2008; 14:1-8.

15. Zhang MH, Zhang AD, Shi ZD, Wang LG, Qiu Y. Changes in levels of seminal nitric oxide synthase, macrophage migration inhibitory factor, sperm DNA integrity and Caspase-3 in fertile men after scrotal heat stress. PLoS One. 2015;10:e0141320.

16. Yin Y, Hawkins KL, DeWolf WC, Morgentaler A. Heat stress causes testicular germ cell apoptosis in adult mice. J Androl. 1997;18:159-65.

17. Desaulniers AT, Lamberson WR, Safranski TJ. Prenatal heat stress reduces male anogenital distance at birth and adult testis size, which are rescued by concurrent maternal Artemisia absinthium consumption. J Therm Biol. 2016; 57:84-91.

18. Kim B, Cooke HJ, Rhee K. DAZL is essential for stress granule formation implicated in germ cell survival upon heat stress. Development. 2012;139: 568-78.

19. Tegelenbosch RA, de Rooij DG. A quantitative study of spermatogonial multiplication and stem cell renewal in the $\mathrm{C} 3 \mathrm{H} / 101 \mathrm{~F} 1$ hybrid mouse. Mutat Res. 1993;290:193-200.

20. Trapnell C, Pachter L, Salzberg SL. TopHat: discovering splice junctions with RNA-Seq. Bioinformatics. 2009;25:1105-11.

21. Anders S, Pyl PT, Huber W. HTSeq--a Python framework to work with highthroughput sequencing data. Bioinformatics. 2015;31:166-9.

22. Robinson MD, Oshlack A. A scaling normalization method for differential expression analysis of RNA-seq data. Genome Biol. 2010;11:R25.

23. Robinson MD, McCarthy DJ, Smyth GK. edgeR: a Bioconductor package for differential expression analysis of digital gene expression data. Bioinformatics. 2010;26:139-40.

24. Sharma M, Braun RE. Cyclical expression of GDNF is required for spermatogonial stem cell homeostasis. Development. 2018;145:dev151555.

25. Le W, Qi L, Xu C, Xiang Z, Mao Z, Zhang J, Xu J, Wu D. Preliminary study of the homologous recombination repair pathway in mouse spermatogonial stem cells. Andrology. 2018;6:488-97.

26. Kubota H, Brinster RL. Spermatogonial stem cells. Biol Reprod. 2018;99: 52-74.

27. Ikeda M, Kodama H, Fukuda J, Shimizu Y, Murata M, Kumagai J, Tanaka T. Role of radical oxygen species in rat testicular germ cell apoptosis induced by heat stress. Biol Reprod. 1999;61:393-9.

28. Perez-Crespo M, Pintado B, Gutierrez-Adan A. Scrotal heat stress effects on sperm viability, sperm DNA integrity, and the offspring sex ratio in mice. Mol Reprod Dev. 2008:75:40-7.

29. Hansen PJ. Effects of heat stress on mammalian reproduction. Philos Trans $R$ Soc Lond Ser B Biol Sci. 2009:364:3341-50.

30. Tiptanavattana N, Thongkittidilok C, Techakumphu M, Tharasanit T. Characterization and in vitro culture of putative spermatogonial stem cells derived from feline testicular tissue. J Reprod Dev. 2013;59:189-95.

31. Kolasa A, Misiakiewicz K, Marchlewicz M, Wiszniewska B. The generation of spermatogonial stem cells and spermatogonia in mammals. Reprod Biol. 2012;12:5-23.

32. Ma W, Wang J, Gao W, Jia H. The safe recipient of SSC transplantation prepared by heat shock with busulfan treatment in mice. Cell Transplant. 2018:27:1451-8

33. Lue YH, Hikim AP, Swerdloff RS, Im P, Taing KS, Bui T, Leung A, Wang C. Single exposure to heat induces stage-specific germ cell apoptosis in rats: role of intratesticular testosterone on stage specificity. Endocrinology. 1999; 140:1709-17.

34. Rockett JC, Mapp FL, Garges JB, Luft JC, Mori C, Dix DJ. Effects of hyperthermia on spermatogenesis, apoptosis, gene expression, and fertility in adult male mice. Biol Reprod. 2001;65:229-39.
35. Lebedeva LA, Shaposhnikov AV, Panov W, Shidlovskii W. Biological functions of Jak/Stat signaling pathway in Drosophila. Genetika. 2013:49: 1245-50.

36. Li C, Shridhar K, Liu J. Molecular characterization of oncostatin M-induced growth arrest of MCF-7 cells expressing a temperature-sensitive mutant of p53. Breast Cancer Res Treat. 2003:80:23-37.

37. Lapeire L, Hendrix A, Lambein K, Van Bockstal M, Braems G, Van Den Broecke R, Limame R, Mestdagh P, Vandesompele J, Vanhove C, Maynard D, Lehuede C, Muller C, Valet P, Gespach CP, Bracke M, Cocquyt V, Denys H, De Wever $\mathrm{O}$. Cancer-associated adipose tissue promotes breast cancer progression by paracrine oncostatin M and Jak/STAT3 signaling. Cancer Res. 2014;74:6806-19.

38. Snyder M, Huang XY, Zhang JJ. Signal transducers and activators of transcription 3 (STAT3) directly regulates cytokine-induced fascin expression and is required for breast cancer cell migration. J Biol Chem. 2011;286: 38886-93.

39. Queen MM, Ryan RE, Holzer RG, Keller-Peck CR, Jorcyk CL. Breast cancer cells stimulate neutrophils to produce oncostatin M: potential implications for tumor progression. Cancer Res. 2005;65:8896-904.

40. Oatley JM, Kaucher AV, Avarbock MR, Brinster RL. Regulation of mouse spermatogonial stem cell differentiation by STAT3 signaling. Biol Reprod. 2010;83:427-33.

41. Herrera SC, Bach EA. JAK/STAT signaling in stem cells and regeneration: from Drosophila to vertebrates. Development. 2019;146:dev167643.

42. Brawley C, Matunis E. Regeneration of male germline stem cells by spermatogonial dedifferentiation in vivo. Science. 2004;304:1331-4.

43. Zhang Y, Zhang L, Zuo Q, Wang Y, Zhang Y, Xu Q, Li B, Chen G. JAK-STAT signaling regulation of chicken embryonic stem cell differentiation into male germ cells. In Vitro Cell Dev Biol Anim. 2017;53:728-43.

44. Abraham AG, O'Neill E. PI3K/Akt-mediated regulation of p53 in cancer. Biochem Soc Trans. 2014;42:798-803.

45. Choy MK, Movassagh M, Bennett MR, Foo RS. PKB/Akt activation inhibits p53-mediated HIF1A degradation that is independent of MDM2. J Cell Physiol. 2010;222:635-9.

46. Ogawara Y, Kishishita S, Obata T, Isazawa Y, Suzuki T, Tanaka K, Masuyama N, Gotoh Y. Akt enhances Mdm2-mediated ubiquitination and degradation of p53. J Biol Chem. 2002;277:21843-50.

\section{Publisher's Note}

Springer Nature remains neutral with regard to jurisdictional claims in published maps and institutional affiliations.

Ready to submit your research? Choose BMC and benefit from:

- fast, convenient online submission

- thorough peer review by experienced researchers in your field

- rapid publication on acceptance

- support for research data, including large and complex data types

- gold Open Access which fosters wider collaboration and increased citations

- maximum visibility for your research: over $100 \mathrm{M}$ website views per year

At BMC, research is always in progress.

Learn more biomedcentral.com/submissions 